\title{
49. 術後の顔貌を考慮した上顎癌手術の検討
}

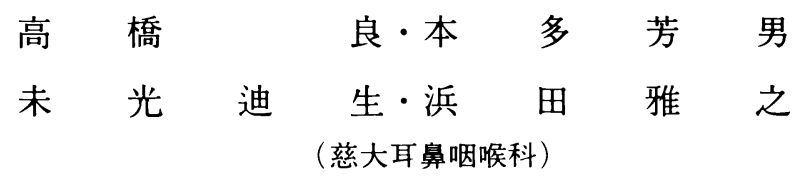

最近，上顎癌に対する治療方針は，固定して来てい る様に思われる。

我々の教室においては, 目下いわゆる三者併用療法 に主眼を打いている。すなわち，放射線照射，抗癌凨 の同時併用の後，種々の程度の摘出術を実施している。 その際, 摘出範囲は腫瘍の進展状態によって決定され, 症例によっては眼窩内容の摘出を含吉搪大した全摘出 術を実施することもある。

しかし, 腫瘍の存在部位, 患者の希望等によっては, 上凝の部分切除に留めることもある、ここに報告する 2 例は, 幸いにも, 部分切除可能と考之られ, 術後の 顔貌を考慮して保存的根治手術を実施したものである。

第 1 例 37歳, 主婦。左側中鼻道に壊死組識を伴う 出血性腫場あり,この一部を組織診断するに, Epider moid carcinoma 診断される。即刻入院し, 左浅側頭 動脈より10回にわたりBleomycin 50mg注入すると同 時に49日間に, Liniac照射6000R実施する。その後, 左
上顎分部切除術を施行した。

第 2 例 45 歳，主婦，右鼻出血あり，右鼻内に中甲 介と一致する部位に, 出血性腫瘍を認めた。入院の上, 組織診断を行うに, Epidermoid carcinoma と解答があ った。第 1 例と同粎, 右浅側頭動脈より Bleomycin150 mg注入し同時に, Liniac 4000R施行後, 右上額部分切 除術を施行した。

以上の 2 例は, いずれも部分切除が可能と考えられ たので, 術前にLiniac照射と抗癌剂の投与を行った後, 手術を施行したものである。

手術の要点は, 2 例とも, 経口的に, 上頡部を露出 して, 下眼窩縁の骨部を橋状に残しさらに䫅骨と口蓋 の骨部を保存する。又, 除去する範囲は, 鼻腔側壁, 笠骨, 蝶形骨ならびに翼状突起などである。

従って, 上顎洞, 鼻腔その他の副鼻腔を始め翼口蓄 窩の清掃は可能である。 